\title{
Thyroid Status, Growth And Development Of Children Under 2 Years Of Age In Endemic Goiter Areas Of Srumbung Magelang
}

\section{Zulkhah Noor ${ }^{1}$, Bambang Edi Susyanto ${ }^{2}$, Anindhita Mega Praningwestri ${ }^{3}$, Aspar Rafiq $^{3}$, Fajar Avivul Havis ${ }^{3}$, Sri Kadarsih Soejono ${ }^{4}$}

:'Department of Physiology, Faculty of Medicine and Health Science, Universitas Muhammadiyah Yogyakarta, ${ }^{2}$ Department of paediatric, Faculty of Medicine and Health Science, Universitas Muhammadiyah Yogyakarta, ${ }^{3}$ undergraduate students Faculty of Medicine and Health Science, Universitas Muhammadiyah Yogyakarta, ${ }^{4}$ Department of Physiology, Faculty of Medicine, Universitas Gadjah Mada Yogyakarta

\begin{abstract}
Objective. To examine the relationship of Iodine urine, TSH and free T4 levels with the growth and development of children under 2 years of age in endemic areas of IDD in Srumbung District, Magelang

Subjects and methods. Respondents of this study were 43 respondents mother and her child under 2 years of age who are still breastfeeding. The study was conducted in March until June 2013. The method used was observational and cross-sectional data retrieved. Mother urine iodine levels were measured in the laboratory GAKI Borobudur Magelang Indonesia. Levels of serum TSH and free T4 were measured by ELISA in the Clinical Laboratory AMC Yogyakarta with TSH ELISA reagents AIM and AIM fT4 ELISA TEST TEST (PT Intan Accurate Madya). Physical growth include weight, height, head circumference, and upper arm circumference. Weight measured in kilograms (kg), followed by calculation of BMI. Upper arm circumference were measured using standard Wolanski. Child development assessment performed using DDST-II (Denver Development Screening Test II). Data were analyzed with the Pearson correlation test for normal data and Spearman correlation for the data is not normal.

Result. Ngargosoko Srumbung Magelang currently have adequate iodine intake with a median urinary iodine concentration of $296 \mathrm{ug} / \mathrm{dL}$, mean blood levels of TSH and fT4 respectively is $1.7187 \mu \mathrm{IU} / \mathrm{mL}$ and $0.8545 \mathrm{ng} / \mathrm{dL}$. But still obtained at $50.84 \%$ of respondents hypothyroidism.

Conclutions. Free thyroxine blood levels determine body weight, body length and arm circumference, but did not determine the amount of head circumference, body mass index, the development of gross motor, fine motor, language and personal social. Child development needs to be measured with a measuring device better example with the Bayley Scale of Infant Development (BSID).
\end{abstract}

Key words. Thyroid status, growth and development, under 2 years old, IDD endemic

\section{PENDAHULUAN}

Kadar Yodium tanah yang rendah dan goitrogen menyebabkan banyak wilayah di Indonesia menjadi daerah endemic gondok. Penelitian mengenai kecukupan kadar $\mathrm{T}_{4}$ dan pengaruhnya pada balita di daerah endemik sangatlah penting untuk menentukan Quality of Life maupun kapasitas sumber daya manusia di suatu daerah endemik ${ }^{1}$. Berbagai faktor menyebabkan penurunan sensitifitas terhadap hormon tiroid antara lain adanya defek pada masuknya hormon tiroid ke dalam sel, metabolisme dan distribusi intraseluler, efek sitosol/non genomik, pengikatan pada reseptor dan translasi 
pada inti, atau abnormalitas ko-regulator lanjutan setelah pengikatan reseptor ${ }^{2}$.

Anak-anak yang lahir dari ibu hipotiroid akan mengalami hipotiroid congenital dan telah diyakini sebagai penyebab disabilitas intelektual yang dapat dicegah. Skrining dengan palpasi memberi hasil yang sangat lemah berkorelasi dengan gangguan fisik ${ }^{3}$. Kadar TSH neonatus telah terbukti berhubungan dengan perkembangan neurokognitif anak ${ }^{4}$. Anak-anak dan remaja hipotiroid subklinis mengalami penurunan kemampuan atensi secara bermaksa ${ }^{5}$.

Pada daerah dengan defisiensi iodine, insiden $\mathrm{HK}$ lebih tinggi antara 1 per 500 hingga 1.500 kelahiran hidup dan dapat mencapai 1 per 141 kelahiran hidup pada bayi dengan Sindrom Down (SD) ${ }^{6}$. Studi lokal di daerah defisiensi yodium, di Yogyakarta didapatkan insiden HK primer 1: 1.500 dan insiden HK transient adalah 1: 300 bayi, oleh karena defisiensi yodium ${ }^{7}$.

Perkembangan sel otak terjadi dengan pesat pada janin dan anak sampai usia dua tahun, karena itu ibu hamil penderita GAKI tingkat ringan dapat memberikan dampak buruk pada perkembangan syaraf motorik dan kognitif janin yang berkaitan dengan perkembangan kecerdasan anak. Penelitian Noor dkk (2009) menemukan sebanyak $40 \%$ remaja mengalami hipotiroid di daerah endemic gondok memiliki skor IQ rata-rata bawah hingga sangat kurang ${ }^{8}$.

Penelitian menunjukkan perempuan dengan tiroid underactive selama kehamilan adalah 4 kali lebih besar memiliki anak dengan nilai IQ lebih rendah. Studi menunjukkan 19\% anakanak lahir dari ibu hipotiroid mempunyai IQ 85 atau kurang. Ini dibandingkan dengan penurunan level IQ hanya 5\% dari bayi dengan ibu tanpa kelainan tiroid, nilai di bawah 85 dapat signifikan bagi anakanak 9 . Rendahnya IQ dianalogkan dengan hasil penelitian struktur otak tikus hipotiroid, yaitu terjadi gangguan pertumbuhan myelinisasi, pembentukan denritik-spine, gangguan migrasi sel di korteks, serebelum maupun hippokampus tikus. Penurunan kadar mRNA myelin basic protein 4 kali lebih lendah pada tikus hipotiroid dibanding normal ${ }^{10}$. Terdapat minimal brain damage di daerah yang terkesan sudah Iodiume replete, dengan IQ point yang terlambat 10-15 point meskipun status tiroid sudah kembali normal, ada keterlambatan perkembangan fisik anak, misalnya lambatnya mengangkat kepala, tengkurap, berjalan, hiporefleksi, strabismus konvergen, hipotoni otot ${ }^{11}$

Penelitian ini bertujuan untuk mengetahui dan mengkaji hubungan kadar yodium urin, TSH dan T4 bebas dengan pertumbuhan dan perkembangan anak usia bawah 2 tahun di daerah endemik 
GAKY di Kecamatan Srumbung, Magelang.

\section{SUBYEK DAN METODE}

Sebanyak 43 responden ibu dan anaknya usia bawah 2 tahun yang masih menyusu telah bersedia menjadi responden penelitian. Responden penelitian ini berasal dari seluruh dusun yang berada di desa Ngargosoko Kecamatan Srumbung Kabupaten Magelang. Kecamatan Srumbung merupakan salah satu kecamatan yang pernah menyandang status endemic GAKI berat yang sekarang telah menjadi daerah endemic GAKI ringan. Penelitian ini dilakukan pada bulan Maret sampai dengan Juni 2013.

Penelitian ini menggunakan metode observasional dan data yang diambil secara cross sectional untuk mengetahui hubungan antara kadar TSH dan $\mathrm{fT}_{4}$ dengan tumbuh kembang anak usia bawah 2 tahun di daerah endemik GAKY Desa Ngargosoko, Kecamatan Srumbung, Kabupaten Magelang.

Kadar yodium urin Ibu diukur di laboratorium GAKI Borobudur Magelang Indonesia. Kadar TSH dan T4 bebas serum diukur dengan metode ELISA di Laboratorium Klinik AMC Yogyakarta dengan reagen AIM TSH ELISA TEST dan AIM fT4 ELISA TEST (PT Akurat Intan Madya).

Pertumbuhan Fisik anak dinilai dengan mengukur antopometri seiring berjalannya waktu (CDC, 2007) meliputi berat badan, tinggi badan, lingkar kepala, dan lingkar lengan atas. Berat badan diukur dengan satuan kilogram $(\mathrm{Kg})$. Setelah mendapatkan hasil dalam $\mathrm{Kg}$, kemudian dikonversikan menjadi persentil dengan kurva pertumbuhan CDC, yaitu kurva berat badan terhadap umur, yang dibedakan antara laki-laki dan perempuan. Setelah dikonversikan maka akan didapatkan skala ordinal kurus $(<5$ persentil), normal (6-95 persentil), gemuk (>95 persentil). Tinggi/panjang badan merupakan panjang sumbu tubuh yang diukur dari kaki sampai vertex. Tinggi/panjang badan diukur dengan infantometer untuk mendapatkan hasil dalam centimeter (cm). Setelah mendapatkan hasil dalam $\mathrm{cm}$, hasil dikonversikan menjadi persentil dengan kurva pertumbuhan CDC. Lingkar kepala merupakan cerminan volume intrakranial dan dipakai untuk menaksir pertumbuhan otak. Lingkar kepala diukur menggunakan pita pengukur, kemudian hasilnya dikonversikan menurut pertumbuhan CDC, yaitu kurva lingkar kepala terhadap umur, yang berbeda antara laki-laki dan perempuan. Lingkar lengan atas merupakan cerminan tumbuh kembang jaringan lemak dan otot yang tidak berpengaruh banyak oleh cairan tubuh. Lingkar lengan atas diukur menggunakan baku Wolanski. Termasuk mengukur lipatan kulit subscapula dan tricep. 
Perkembangan adalah bertambahnya struktur dan fungsi tubuh yang lebih kompleks dalam kemampuan gerak kasar, gerak halus, bicara dan bahasa serta sosialisasi dan kemandirian. Perkembangan motorik kasar adalah aspek yang berhubungan dengan kemampuan anak melakukan pergerakan dan sikap tubuh yang melibatkan otototot besar seperti duduk, berdiri dan sebagainya. Perkembangan motorik halus adalah aspek yang berhubungan dengan kemampuan anak melakukan gerakan yang melibatkan bagian-bagian tubuh tertentu dan dilakukan oleh otot-otot kecil, tetapi memerlukan koordinasi yang cermat seperti mengamati sesuatu, menjepit, menulis dan sebagainya ${ }^{12}$. Penilaian perkembangan anak dilakukan dengan menggunakan DDST-II (Denver Development Screening Test II).

Data yang telah diperoleh diedit, ditabulasi, selanjutnya ditanpilkan dalam bentuk sebaran (data terendah, tertinggi dan rerata) dan dilakukan penghitungan distribusi frekwensi. Uji nornalitas data untuk menentukan analisis statistik korelasi yang dipilih, yaitu korelasi Pearson untuk data normal dan korelasi Spearman untuk data tidak normal.

\section{HASIL}

Pengambilan sampel urin dan darah dilaksanakan secara serentak pada tanggal 8 Juni 2013, di Ngargosoko Kecamatan
Srumbung, di hadiri oleh 50 responden ibu dan 50 responden anak usia bawah 2 tahun yang berdomisili di Dusun Bendan, Gedangan, Krajan Ngargosoko, Ngargosoka Wetan, Tempel, Warudoyong. Mereka adalah penduduk asli setempat.

Tabel 1. Menunjukkan bahwa terdapat 23,3\% anak lahir preterm dan berat badan lahir kurang dari 2,5kg, dan sebanyak $16.8 \%$ tidak mendapat ASI eksklusif.

Tabel 2. Menunjukkan bahwa rentang kadar Iodium urin Ibu sangat lebar mula dari 42 ug/dL-500 ug/dL dengan nilai tengah 296 ug/dL. Secara statistik, rata-rata kadar tiroksin bebas darah dan TSH anak usia bawah 2 tahun berada pada kelompok normal, dengan kadar terendah $\mathrm{fT}_{4} 0,383 \mathrm{ng} / \mathrm{dL}$ dan nilai terendah untuk TSH 0,26 $\mu \mathrm{IU} / \mathrm{ml}$. Sementara untuk kadar tertinggi $\mathrm{fT}_{4}$ dan TSH ialah 1,793 ng/dL dan 7,01 $\mu \mathrm{IU} / \mathrm{ml}$, di mana walaupun kadar tertinggi $\mathrm{fT}_{4}$ masih berada dalam kategori normal, tetapi kadar tertinggi TSH masuk ke dalam kategori meningkat sedang. 
Tabel 1. Karakteristik Responden Anak usia Bawah 2 tahun

\begin{tabular}{|c|c|c|c|c|}
\hline \multirow{2}{*}{ No } & \multirow{2}{*}{ KRITERIA } & \multicolumn{3}{|c|}{ TOTAL } \\
\hline & & $\mathbf{n}$ & $\%$ & $\sum n$ \\
\hline \multirow{3}{*}{1} & \multicolumn{4}{|l|}{ Usia } \\
\hline & $0-12$ bulan & 22 & 51.2 & \multirow{2}{*}{43} \\
\hline & 13-24 bulan & 21 & 48.8 & \\
\hline \multirow{3}{*}{2} & \multicolumn{4}{|c|}{ Jenis kelamin } \\
\hline & Laki-laki & 22 & 51.2 & \multirow{2}{*}{43} \\
\hline & Perempuan & 21 & 48.8 & \\
\hline \multirow{4}{*}{3} & \multicolumn{4}{|c|}{ Usia kehamilan } \\
\hline & aterm & 33 & 76.7 & \multirow{3}{*}{43} \\
\hline & preterm & 10 & 23.3 & \\
\hline & posterm & 0 & 0.0 & \\
\hline \multirow{4}{*}{4} & \multicolumn{4}{|l|}{ Berat lahir } \\
\hline & $<2,5$ & 10 & 23.3 & \multirow{3}{*}{43} \\
\hline & $2,5-4$ & 32 & 74.4 & \\
\hline & $>4$ & 1 & 2.3 & \\
\hline \multirow{3}{*}{5} & \multicolumn{4}{|c|}{ Pemberian ASI eksklusif } \\
\hline & $\mathrm{Ya}$ & 35 & 81.4 & 13 \\
\hline & Tidak & 8 & 18.6 & 43 \\
\hline \multirow{3}{*}{6} & \multicolumn{4}{|c|}{ Pembesaran leher } \\
\hline & Normal & 43 & 100.0 & \multirow{2}{*}{43} \\
\hline & Suspek & 0 & 0 & \\
\hline
\end{tabular}

Tabel 2. Gambaran Status Iodium urin, TSH dan $\mathrm{fT}_{4}$ anak usia bawah 2 tahun di Desa Ngargosoko Srumbung, Magelang

\begin{tabular}{|l|c|c|c|c|}
\hline \multicolumn{1}{|c|}{ Kriteria } & $\mathbf{n}$ & $\begin{array}{c}\text { Kadar Iodium } \\
\text { Urin }(\mathbf{u g} / \mathbf{L})\end{array}$ & $\begin{array}{c}\text { Nilai } \mathbf{f T}_{\mathbf{4}} \text { Darah } \\
(\mathbf{n g} / \mathbf{d L})\end{array}$ & $\begin{array}{c}\text { Nilai TSH darah } \\
(\mu \mathbf{I U} / \mathbf{m l})\end{array}$ \\
\hline $\begin{array}{l}\text { Kadar } \\
\text { Terendah }\end{array}$ & - & 41 & 0,383 & 0.26 \\
\hline $\begin{array}{l}\text { Kadar } \\
\text { Tertinggi }\end{array}$ & - & 503 & 1,793 & 7.01 \\
\hline Median & 43 & 296 & 0.792 & 1.5 \\
\hline Rata-Rata & 43 & 301.7209 & 0.8545 & 1.7187 \\
\hline $\begin{array}{l}\text { Standar } \\
\text { Deviasi }\end{array}$ & 43 & 114.6584 & 0.30591 & 1.35884 \\
\hline
\end{tabular}


Tabel 3. Sebaran Frekuensi Status Tiroid responden anak usia bawah 2 tahun ditinjau dari kadar TSH dan T4 darah

\begin{tabular}{|c|c|c|c|c|c|c|c|c|c|}
\hline \multirow{3}{*}{$\begin{array}{l}\mathbf{N} \\
\mathbf{O}\end{array}$} & \multirow{3}{*}{$\begin{array}{l}\text { STATUS } \\
\text { TSH }\end{array}$} & \multirow{3}{*}{$\mathbf{N}$} & \multirow{3}{*}{$\%$} & \multicolumn{6}{|c|}{ STATUS $T_{4}$ BEBAS } \\
\hline & & & & \multicolumn{3}{|c|}{$\begin{array}{c}\text { RENDAH }(<0.8 \\
\text { ngdL) }\end{array}$} & \multicolumn{3}{|c|}{$\begin{array}{c}\text { NORMAL }(0.8-2,0 \\
\mathrm{ng} / \mathrm{dL})\end{array}$} \\
\hline & & & & $\mathbf{N}$ & $\%$ & KET & $\mathbf{N}$ & $\%$ & KET \\
\hline 1 & $\begin{array}{c}\text { Rendah } \\
(<0.4 \mu \mathrm{IU} / \mathrm{dL})\end{array}$ & 2 & 4,65 & 1 & 2,33 & $\begin{array}{c}\text { Hipotiroi } \\
\mathrm{d} \\
\text { sekunder } \\
/ \\
\text { tersier }\end{array}$ & 1 & 2,35 & $\begin{array}{l}\text { Bukan } \\
\text { penyakit } \\
\text { tiroid }\end{array}$ \\
\hline 2 & $\begin{array}{l}\text { Normal } \\
(0.4-2,49 \\
\mu \mathrm{IU} / \mathrm{dL})\end{array}$ & 34 & 79 & 16 & 37,2 & $\begin{array}{c}\text { Hipotiroi } \\
\mathrm{d} \\
\text { sekunder } \\
/ \\
\text { tersier }\end{array}$ & 20 & 46,5 & eutiroid \\
\hline 3 & $\begin{array}{c}\text { Meningkat } \\
\text { ringan (Resiko) } \\
(2.5-3.99 \\
\mu \mathrm{IU} / \mathrm{dL})\end{array}$ & 4 & 9,4 & 1 & 2,33 & $\begin{array}{l}\text { Hipotiroi } \\
\text { d primer }\end{array}$ & 3 & 7 & $\begin{array}{l}\text { Hipotiroi } \\
\mathrm{d} \\
\text { subklinik }\end{array}$ \\
\hline 4 & $\begin{array}{c}\text { Meningkat } \\
\text { sedang } \\
(4-10 \mu \mathrm{IU} / \mathrm{dL})\end{array}$ & 3 & 4,65 & 2 & 4,66 & $\begin{array}{l}\text { Hipotiroi } \\
\text { d primer }\end{array}$ & 1 & 2,33 & $\begin{array}{c}\text { Hipotiroi } \\
\mathrm{d} \\
\text { subklinik }\end{array}$ \\
\hline
\end{tabular}

Tabel 3. memperlihatkan bahwa hanya $20(46,5 \%)$ dari 43 anak usia bawah 2 tahun di Desa Ngargosoko yang memiliki fungsi tiroid normal (eutiroid). Lebih dari separuh anak usia bawah 2 tahun di Desa Ngargosoka memiliki kadar tiroksin bebas yang rendah dalam tubuh mereka dengan rasio antara kelompok hipotiroid dan eutiroid sebesar 53,5\% : 46,5\%. Untuk kelompok hipotiroid sendiri, didapatkan anak dengan status hipotiroid sekunder/tersier, hipotiroid primer, dan hipotiroid subklinik masingmasing sebesar $73,9 \% ; 13 \% ; 17,3 \%$. Sementara frekuensi tertinggi gangguan fungsi tiroid ditemukan pada kelompok subjek dengan kadar TSH normal dan $\mathrm{fT}_{4}$ rendah.

Tabel 4. menunjukkan bahwa 4 $(80 \%)$ dari 5 anak berat badan kurang dan buruk memiliki kadar $\mathrm{fT}_{4}$ yang rendah.
Hasil analisis uji korelasi Spearman, hubungan $\mathrm{fT}_{4}$ dengan berat badan anak bawah dua tahun diperoleh nilai $\mathrm{p}=0,004$ $(\mathrm{p}<0,05)$ yang menunjukkan terdapat korelasi yang bermakna antara dua variabel yang diuji dengan kekuatan korelasi sedang $(r=0,426)$ dan arah korelasi positif menunjukkan semakin tinggi kadar $\mathrm{fT}_{4}$ seorang anak maka akan semakin baik berat badan anak tersebut.

Distribusi status pertumbuhan panjang badan anak usia bawah dua tahun di Kecamatan Srumbung secara umum menunjukkan 14 (32,5\%) dari 43 anak memiliki postur pendek (32,5\%), dan 78\%-nya merupakan anak dengan kadar $\mathrm{fT}_{4}$ rendah. Hasil analisis korelasi Spearman menunjukkan $\mathrm{p}=0,011(<0,05)$ maka terdapat korelasi signifikan di antara kedua variabel, dengan kekuatan korelasi lemah $(r<0,399)$ dan arah korelasi positif. 
Tabel 6 menunjukkan terdapat 3 anak dengan lingkar kepala $<5^{\text {th }}$ persentil dan $>95^{\text {th }}$ persentil dan ketiganya merupakan anak dengan status fT4 rendah. Sesuai dengan interpretasi data persentil WHO, maka ketiga anak ini akan mengalami gangguan perkembangan mental. Hasil analisis data menunjukkan nilai $\mathrm{p}=0,309$ $(>0,05)$ maka tidak terdapat korelasi signifikan di antara kedua variabel.

Tabel 4. Sebaran Frekuensi Berat Badan berdasar Status $\mathrm{fT}_{4}$

\begin{tabular}{|c|c|c|c|c|c|c|c|c|}
\hline \multirow{2}{*}{ No } & \multirow{2}{*}{ Status f $\mathbf{f T}_{\mathbf{4}}$} & \multicolumn{2}{|c|}{ Baik } & \multicolumn{2}{|c|}{ Kurang } & \multicolumn{2}{|c|}{ Buruk } & \multirow{2}{*}{$\begin{array}{c}\text { Uji Korelasi } \\
\text { Spearman }\end{array}$} \\
\cline { 3 - 8 } & & $\mathbf{n}$ & $\mathbf{\%}$ & $\mathbf{n}$ & $\mathbf{\%}$ & $\mathbf{n}$ & $\mathbf{\%}$ & \\
\hline 1 & Rendah & 19 & 44,1 & 3 & 6,9 & 1 & 2,3 & \multirow{2}{*}{$\begin{array}{c}\mathrm{p}=0,004 \\
\mathrm{r}=0,426\end{array}$} \\
\hline 2 & Optimum & 19 & 44,1 & 1 & 2,3 & 0 & 0 & \\
\hline & Total & 38 & 88,3 & 4 & 9,3 & 1 & 2,3 & \\
\hline
\end{tabular}

Tabel 5. Sebaran Frekuensi Panjang Badan berdasar Status $\mathrm{fT}_{4}$

\begin{tabular}{|c|c|c|c|c|c|c|}
\hline \multirow{3}{*}{ No } & \multirow{3}{*}{ Status $\mathbf{f T}_{4}$} & \multicolumn{4}{|c|}{ Panjang Badan Anak } & \multirow{3}{*}{$\begin{array}{c}\text { Uji } \\
\text { Korelasi } \\
\text { Spearman }\end{array}$} \\
\hline & & \multicolumn{2}{|c|}{ Pendek } & \multicolumn{2}{|c|}{ Normal } & \\
\hline & & $\mathbf{N}$ & $\%$ & $\mathbf{n}$ & $\%$ & \\
\hline 1 & Rendah & 11 & 25,53 & 12 & 27,9 & \multirow{3}{*}{$\begin{array}{c}\mathrm{p}=0,011 \\
\mathrm{r}=0,397\end{array}$} \\
\hline \multirow[t]{2}{*}{2} & Optimum & 3 & 6,9 & 17 & 39,5 & \\
\hline & Total & 14 & 32,5 & 29 & 67,4 & \\
\hline
\end{tabular}

Tabel 6. Sebaran Frekuensi Lingkar Kepala berdasar Status $\mathrm{fT}_{4}$

\begin{tabular}{|c|c|c|c|c|c|c|c|c|}
\hline \multirow{3}{*}{ No } & \multirow{3}{*}{ Status $\mathrm{fT}_{4}$} & \multicolumn{6}{|c|}{ Lingkar Kepala } & \multirow{3}{*}{$\begin{array}{c}\text { Uji Korelasi } \\
\text { Spearman }\end{array}$} \\
\hline & & \multicolumn{2}{|c|}{ Persentil $<5^{\text {th }}$} & \multicolumn{2}{|c|}{$\begin{array}{c}\text { Persentil } \\
5^{\text {th }}-95^{\text {th }}\end{array}$} & \multicolumn{2}{|c|}{$\begin{array}{c}\text { Persentil } \\
>95^{\text {th }}\end{array}$} & \\
\hline & & $\mathbf{n}$ & $\%$ & $\mathbf{n}$ & $\%$ & $\mathbf{N}$ & $\%$ & \\
\hline 1 & Rendah & 2 & 4,6 & 18 & 41,8 & 1 & 2,3 & \multirow{3}{*}{$\begin{array}{l}\mathrm{p}=0,309 \\
\mathrm{r}=0,056\end{array}$} \\
\hline 2 & Optimum & 0 & 0 & 18 & 41,8 & 0 & 0 & \\
\hline & Total & 2 & 4,6 & 36 & 83,7 & 1 & 2,3 & \\
\hline
\end{tabular}


Tabel 7. Sebaran Frekuensi Lingkar Lengan Atas berdasar Status fT4

\begin{tabular}{|c|c|c|c|c|c|c|c|c|}
\hline \multirow{3}{*}{ No } & \multirow{3}{*}{ Status $\mathrm{fT}_{4}$} & \multicolumn{6}{|c|}{ Lingkar Lengan Atas } & \multirow{3}{*}{$\begin{array}{c}\text { Uji Korelasi } \\
\text { Spearman }\end{array}$} \\
\hline & & \multicolumn{2}{|c|}{$\begin{array}{c}\text { Persentil } \\
<5^{\text {th }}\end{array}$} & \multicolumn{2}{|c|}{$\begin{array}{l}\text { Persentil } \\
85^{\text {th }}-95^{\text {th }}\end{array}$} & \multicolumn{2}{|c|}{$\begin{array}{c}\text { Persentil } \\
>95^{\text {th }}\end{array}$} & \\
\hline & & n & $\%$ & $n$ & $\%$ & $\mathbf{n}$ & $\%$ & \\
\hline 1 & Rendah & 2 & 2,3 & 12 & 27,9 & 4 & 9,3 & \multirow{3}{*}{$\begin{array}{l}\mathrm{p}=0,041 \\
\mathrm{r}=-0,342\end{array}$} \\
\hline \multirow[t]{2}{*}{2} & Optimum & 0 & 0 & 13 & 30,2 & 4 & 9,3 & \\
\hline & Total* & 2 & 2,3 & 25 & 58,1 & 8 & 18,6 & \\
\hline
\end{tabular}

*)Missing data : 8

Tabel 7. Menunjukkan terdapat $23,2 \%$ anak berada di luar batas normal persentil lingkar lengan atas, $60 \%$ nya merupakan anak dengan fT4. Sementara itu 50\% dari anak yang berada pada kategori di atas persentil ke-95 merupakan anak dengan kadar $\mathrm{fT}_{4}$ yang rendah. Hasil analisis data menggunakan uji korelasi Spearman, hubungan $\mathrm{fT}_{4}$ dengan lingkar lengan atas anak bawah dua tahun memiliki nilai $\mathrm{p}=0,041 \quad(\mathrm{p}<0,05)$ yang menunjukkan terdapat korelasi yang bermakna dengan kekuatan korelasi lemah (r antara 0,30 - 0,499) dan arah korelasi neegatif, di mana kenaikan satu variabel akan menurunkan variabel lainnya.

Tabel 8 menunjukkan terdapat $6,9 \%$, 4,6\% dan 6,9\% sampel yang dikategorikan underweight, resiko overweight dan overweight. $50 \%$ nya merupakan anak dengan $\mathrm{fT}_{4}$ rendah. Tidak terdapat korelasi signifikan $(\mathrm{p}>0,05)$ antara BMI dengan kadar $\mathrm{fT}_{4}$ anak.
Tabel 9 memperlihatkan hasil pemeriksaan $\mathrm{fT}_{4}$ darah didapatkan adanya 36 anak dengan perkembangan motorik kasar normal, 5 anak $(11,62 \%)$ dicurigai mengalami keterlambatan dengan T4 rendah dan optimal, dan 2 (4,65\%) anak tidak dapat dites. Uji korelasi Spearmandiperoleh nilai $\mathrm{p}=0,212(\mathrm{p}>$ $0,05)$ yang menunjukan tidak terdapat korelasi yang bermakna antara status $\mathrm{fT}_{4}$ dengan status perkembangan motorik kasar anak usia bawah dua tahun di daerah endemik GAKY.

Tabel 10 memperlihatkan terdapat $6(13,95 \%)$ anak dicurigai mengalami keterlambatan, dan 1 (2,32\%) anak tidak dapat dites. Uji korelasi Spearman didapatkan nilai $\mathrm{p}=0,366(\mathrm{p}>0,05)$ yang menunjukan tidak terdapat korelasi yang bermakna antara status $\mathrm{fT}_{4}$ dengan status perkembangan motorik halus anak usia bawah dua tahun di Ngargosoko Srumbung

Magelang. 
Tabel 8. Sebaran Frekuensi BMI berdasar Status $\mathrm{fT}_{4}$

\begin{tabular}{|c|c|c|c|c|c|c|c|c|c|c|}
\hline \multirow{3}{*}{ No } & \multirow{3}{*}{ Status $\mathrm{fT}_{4}$} & \multicolumn{8}{|c|}{ Body Mass Index } & \multirow{3}{*}{$\begin{array}{c}\text { Uji Korelasi } \\
\text { Spearman }\end{array}$} \\
\hline & & \multicolumn{2}{|c|}{$\begin{array}{c}\text { Persentil } \\
<5^{\text {th }}\end{array}$} & \multicolumn{2}{|c|}{$\begin{array}{l}\text { Persentil } \\
5^{\text {th }}-85^{\text {th }}\end{array}$} & \multicolumn{2}{|c|}{$\begin{array}{c}\text { Persentil } \\
>85^{\text {th }}-95^{\text {th }}\end{array}$} & \multicolumn{2}{|c|}{$\begin{array}{c}\text { Persentil } \\
>95^{\text {th }}\end{array}$} & \\
\hline & & $\mathrm{n}$ & $\%$ & n & $\%$ & $\mathrm{n}$ & $\%$ & $\mathrm{n}$ & $\%$ & \\
\hline 1 & Rendah & 2 & 4,6 & 19 & 44,1 & 0 & 0 & 2 & 4,6 & \multirow{3}{*}{$\begin{array}{l}\mathrm{p}=0,504 \\
\mathrm{r}=0,106\end{array}$} \\
\hline 2 & Optimum & 1 & 2,3 & 16 & 37,2 & 2 & 4,6 & 1 & 2,3 & \\
\hline & Total* & 3 & 6,9 & 35 & 81,3 & 2 & 4,6 & 3 & 6,9 & \\
\hline
\end{tabular}

Tabel 9. Sebaran Frekuensi Perkembangan Motorik Kasar berdasar Status $\mathrm{fT}_{4}$

\begin{tabular}{|c|c|c|c|c|c|c|c|c|}
\hline \multirow{3}{*}{ No } & \multirow{3}{*}{ Status $\mathrm{fT}_{4}$} & \multicolumn{6}{|c|}{ Perkembangan Motorik Kasar } & \multirow{3}{*}{$\begin{array}{c}\text { Uji Korelasi } \\
\text { Spearman }\end{array}$} \\
\hline & & \multicolumn{2}{|c|}{ Curiga } & \multicolumn{2}{|c|}{ Normal } & \multicolumn{2}{|c|}{$\begin{array}{l}\text { Tidak Dapat } \\
\text { di Uji }\end{array}$} & \\
\hline & & n & $\%$ & $\mathbf{N}$ & $\%$ & n & $\%$ & \\
\hline 1 & Rendah & 2 & 4,65 & 20 & 46,51 & 2 & 4,65 & \multirow{3}{*}{$\begin{array}{l}\mathrm{p}=0,212 \\
\mathrm{r}=-0,194\end{array}$} \\
\hline 2 & Optimum & 3 & 6,97 & 16 & 37,20 & 0 & 0 & \\
\hline & Total & 5 & 11,62 & 36 & 83,71 & 2 & 4,65 & \\
\hline
\end{tabular}

Tabel 10. Sebaran Frekuensi Perkembangan Motorik Halus berdasarkan Status $\mathrm{fT}_{4}$

\begin{tabular}{|c|c|c|c|c|c|c|c|c|}
\hline \multirow{3}{*}{ No } & \multirow{3}{*}{ Status $\mathbf{f T}_{4}$} & \multicolumn{6}{|c|}{ Perkembangan Motorik Halus } & \multirow{3}{*}{$\begin{array}{c}\text { Uji Korelasi } \\
\text { Spearman }\end{array}$} \\
\hline & & \multicolumn{2}{|c|}{ Curiga } & \multicolumn{2}{|c|}{ Normal } & \multicolumn{2}{|c|}{$\begin{array}{c}\text { Tidak } \\
\text { Dapat di } \\
\text { Uji }\end{array}$} & \\
\hline & & n & $\%$ & $\mathrm{n}$ & $\%$ & $\mathbf{N}$ & $\%$ & \\
\hline 1 & Rendah & 4 & 9,30 & 20 & 46,51 & 0 & 0 & \multirow{3}{*}{$\begin{array}{l}\mathrm{p}=0,366 \\
\mathrm{r}=0,141\end{array}$} \\
\hline 2 & Optimum & 2 & 4,65 & 16 & 37,20 & 1 & 2,32 & \\
\hline & Total & 6 & 13,95 & 36 & 83,71 & 1 & 2,32 & \\
\hline
\end{tabular}

Tabel 11. Sebaran Frekuensi Perkembangan Bahasa Berdasarkan Status $\mathrm{fT}_{4}$

\begin{tabular}{|c|c|c|c|c|c|c|c|c|}
\hline \multirow{3}{*}{ No } & \multirow{3}{*}{ Status $\mathbf{f T}_{4}$} & \multicolumn{6}{|c|}{ Perkembangan Bahasa } & \multirow{3}{*}{$\begin{array}{c}\text { Uji Korelasi } \\
\text { Spearman }\end{array}$} \\
\hline & & \multicolumn{2}{|c|}{ Curiga } & \multicolumn{2}{|c|}{ Normal } & \multicolumn{2}{|c|}{$\begin{array}{l}\text { Tidak Dapat } \\
\text { di Uji }\end{array}$} & \\
\hline & & Nilai & $\%$ & Nilai & $\%$ & Nilai & $\%$ & \\
\hline 1 & Rendah & 5 & 11,62 & 18 & 41,86 & 1 & 2,32 & \multirow{3}{*}{$\begin{array}{c}P=0,759 \\
r=-0,048\end{array}$} \\
\hline 2 & Optimum & 5 & 11,62 & 13 & 30,23 & 1 & 2,32 & \\
\hline & Total & 10 & 23,24 & 31 & 72,09 & 2 & 4,64 & \\
\hline
\end{tabular}


Tabel 12. Sebaran Frekuensi Personal Sosial

\begin{tabular}{|c|c|c|c|c|c|c|c|c|}
\hline \multirow{3}{*}{ No } & \multirow{3}{*}{ Status $\mathrm{fT}_{4}$} & \multicolumn{6}{|c|}{ Perkembangan Personal Sosial } & \multirow{3}{*}{$\begin{array}{c}\text { Uji Korelasi } \\
\text { Spearman }\end{array}$} \\
\hline & & \multicolumn{2}{|c|}{ Curiga } & \multicolumn{2}{|c|}{ Normal } & \multicolumn{2}{|c|}{$\begin{array}{l}\text { Tidak Dapat } \\
\text { di Uji }\end{array}$} & \\
\hline & & Nilai & $\%$ & Nilai & $\%$ & Nilai & $\%$ & \\
\hline 1 & Rendah & 1 & 2,32 & 22 & 51,16 & 1 & 2,32 & \multirow{3}{*}{$\begin{array}{l}\mathrm{p}=0,269 \\
\mathrm{r}=-0,172\end{array}$} \\
\hline 2 & Optimum & 2 & 4,65 & 17 & 39,53 & 0 & 0 & \\
\hline & Total & 3 & 6,97 & 39 & 90,69 & 1 & 2,32 & \\
\hline
\end{tabular}

Tabel 11. Memperlihatkan terdapat $10 \quad(23,24 \%)$ anak dicurigai mengalami keterlambatan perkembangan bahasa.

Hasil analisis korelasi Spearman, diperoleh $(p)=0,759(p>0,05)$.

Tabel 12 menunjukkan sebanyak 3 $(6,97 \%)$ anak dicurigai mengalami keterlambatan perkembangan personal social. Hasil analisis data menggunakan uji korelasi Spearman, hubungan antara $\mathrm{fT}_{4}$ dengan status perkembangan personal sosial anak usia di bawah dua tahun memiliki nilai $\mathrm{p}=0,269(\mathrm{p}>0,05)$ yang menunjukan tidak terdapat korelasi yang bermakna antara status $\mathrm{fT}_{4}$ dengan status perkembangan personal sosial anak usia bawah dua tahun.

\section{PEMBAHASAN}

Kependudukan dan lama tinggal merupakan salah satu hal yang perlu dikendalikan karena asal daerah mempengaruhi kecukupan asupan yodium alami maupun program pemerintah di Daerah GAKY. Keadaan tiroid seorang ibu dapat mempengaruhi kadar tiroid anak yang dikandungnya ${ }^{13}$. Berbagai factor ibu yang mempengaruhi tumbuh kembang anak antara lain BMI Orang tua menentukan BMI anak ${ }^{14}$, Usia Ibu saat hamil juga berpengaruh terhadap pertumbuhan janin saat kehamilan. Hal ini berkaitan dengan status mental, kesiapan anatomis ibu dan pengetahuan calon ibu mengenai perawatan anak baru lahir yang masih kurang pada ibu usia bawah 20 tahun $^{15}$.

Usia kehamilan dan berat lahir anak perlu diingat untuk mengetahui proses pertumbuhan anak saat masih berada dalam kandungan ibu. Hal ini berkaitan erat dengan antropometri seorang anak di kemudian hari, karena pertumbuhan paling dramatis terjadi saat berada di dalam kandungan ${ }^{16}$. Indeks hipotiroid yang normal dari seluruh responden menunjukkan tidak terdapat hipotiroid berat di area penelitian.

Pemberian ASI eksklusif berkaitan erat dengan kecukupan asupan gizi untuk pertumbuhan somatik dan perkembangan otak pada awal kehidupan ${ }^{16}$. Hanya 6 $(13,9 \%)$ dari 43 responden atau responden 
yang tidak mendapatkan ASI ekslusif menunjukkan bahwa masyarakat di Desa Ngargosoka telah menyadari manfaat penting dari pemberian ASI eksklusif sehingga sebagian besar warga desa telah melaksanakan ASI ekslusif.

Masih didapatkan kejadian hipotiroid yang cukup tinggi di area penelitian. Didapatkan anak dengan status hipotiroid sekunder/tersier, hipotiroid primer, dan hipotiroid subklinik berturutturut sebesar $73,9 \% ; 13 \% ; 17,3 \%$ untuk kelompok hipotiroid. Sementara frekuensi tertinggi gangguan fungsi tiroid ditemukan pada kelompok subyek dengan kadar TSH normal dan $\mathrm{fT}_{4}$ rendah.

Hipotiroid dibagi menjad primer, dimana gangguan disebabkan oleh kegagalan fungsi tiroid, dan sekunder (sentral) kegagalan sekresi TSH dari hipofisis anterior atau TRH dari hipotalamus. Hipotiroid sekunder dapat dibagi menjadi hipotiroid hipofisis (sekunder) atau hipotiroid hipotalamus (tersier) dengan uji TRH. Kegagalan aksi hormon pada jaringan perifer disebut dengan hipotiroid juga mungkin dapat terjadi. Hipotiroid primer akan mulai menampakkan gejala klinis apabila tiroksin bebas ( $\left.\mathrm{fT}_{4}\right)$ darah menurun sementara TSH meningkat. Apabila $\mathrm{fT}_{4}$ masih normal tetapi TSH meningkat, maka disebut sebagai hipotiroid subklinis. Sementara pada hipotiroid sekunder, $\mathrm{fT}_{4}$ menurun dan TSH normal atau menurun ${ }^{17}$.
Hipotiroid sekunder paling banyak ditemukan pada anak-anak tersebut. Banyak hal yang dapat menyebabkan keadaan hipotiroid sekunder, baik secara genetik, neoplasma, gangguan vaskuler, empty sella syndrome, inflamasi, penyakit infiltratif, trauma kepala, hingga konsumsi obat-obatan ${ }^{18}$. Sehingga tidak dapat ditentukan penyebab pasti dari keadaan ini. Penelitian pada tahun 2013 di Kolkata, India menunjukkan bahwa 55,15\% dari 466 penduduknya mengalami hipotiroid. Hipotiroid itu sendiri dibagibagi menjadi hipotiroid yang menunjukkan gejala klinis dan sub klinis masing-masing sebesar 39,7\% dan 11,8\%. Masih terdapat 17 penduduk yang belum teridentifikasi penyebab dari hipotiroidnya. Penelitian yang dilakukan oleh A.G Unnikrishnan menunjukkan bahwa prevalensi kejadian hipotiroid jauh lebih banyak terjadi pada daerah non-pesisir dibanding daerah pesisir. Anggapan selama ini bahwa GAKY hanya terjadi di dataran tinggi juga perlu dievaluasi kembali dengan ditemukannya endemik GAKY di dataran rendah dan subur di India. Kemungkinan hal ini dapat terjadi disebabkan oleh makanan cyanogenic yang berlaku sebagai goitrogenik dan menggangu asupan nutrisi yodium seperti yang sudah dianjurkan sebelumnya. Penelitian yang dilakukan oleh A.G Unnikrishnan ini juga menunjukkan bahwa prevalensi hipotiroid 
subklinis lebih tinggi pada perempuan daripada laki-laki $(\mathrm{p}=0.0358)^{19}$.

Pada penderita hipotiroid sejak lahir, goiter tidak akan ditemukan dan didapati rendahnya nilai thyroid radioiodine uptake. Kebanyakan bayi dengan kadar $\mathrm{fT}_{4}$ rendah dan kadar TSH yang juga rendah merupakan bayi prematur, yang nantinya akan berkembang menjadi hipotiroksinemia transien premature. Anak-anak dengan keadaan ini akan memiliki postur tubuh pendek, dengan keterlambatan atau bahkan kegagalan pematangan tulang, yang hampir bisa dipastikan konkomitan dengan keadaan defisiensi GH (Growth Hormone) atau hormon pertumbuhan ${ }^{20}$.

Jika defisiensi TSH dicurigai, maka pengukuran $\mathrm{GH}$ dan kortisol dianjurkan untuk dilakukan untuk mengetahui adanya indikasi panhypopituitarism. Adanya gejala seperti hipoglikemi pada bayi baru lahir juga merupakan salah satu tanda kemungkinan terjadinya defisiensi $\mathrm{GH}$ dan/atau adenokortikotropi. Evaluasi lebih lanjut untuk kadar TRH sebaiknya dilakukan, bersama dengan dilakukannya tes pencitraan otak untuk mengidentifikasi anomaly hipotalamushipofisis $^{21}$.

Berdasarkan data yang diambil dari 43 responden didapatkan hasil yaitu anak usia bawah 2 tahun di daerah GAKY, Srumbung, Magelang dengan kadar hormon $\mathrm{fT}_{4}$ rendah adalah 23 orang (53,4 \%) dan anak dengan kadar $\mathrm{fT}_{4}$ normal adalah 20 orang $(46,5 \%)$ hal ini menunjukkan bahwa status hormon $\mathrm{fT}_{4}$ pada anak-anak usia bawah 2 tahun di daerah endemik GAKY masih berada di bawah batas normal/optimum.

Penelitian di Sudan pada tahun 2001 menunjukkan bahwa kadar hormon tiroid ibu dan neonatus yang dinilai dari kadar TSH, Tg, $\mathrm{T}_{3}$ dan $\mathrm{fT}_{4}$ pada daerah endemik GAKY berada pada batas bawah normal yaitu 13,2 (13.4 - 15.9) pmol/L atau setara dengan $0,797(0,8-1,8) \mathrm{ng} / \mathrm{dL}^{22}$. Hal ini dimungkinkan terjadi karena program-program perbaikan dari pemerintah sudah berjalan, tetapi faktorfaktor lain seperti autoimun pada individu tertentu di daerah endemik tersebut. Penelitian terkait mengenai hal ini dilakukan di India bagian utara, di mana 2860 subjek penelitian di daerah endemik GAKY India mendapatkan terapi yodium. Terdapat perbaikan status gondok endemik dari 69\% menjadi $27,7 \%$ di tahun 2007. Tetapi gangguan akibat kekurangan yodium sendiri berupa gondok endemik dan hipotiroid masih sangat tinggi $(>30 \%)$ yaitu $34 \%$ menyebabkan status hormon tiroid populasi tersebut tidak dapat benar-benar optimal23.

Pengukuran lingkar kepala merupakan evaluasi paling sederhana, mendasar, dan murah untuk dilakukan untuk memperkirakan perkembangan system saraf pusat pada neonatus yang berada pada daerah resiko tinggi gangguan 
perkembangan otak ${ }^{24}$. Hasil pengukuran menunjukkan terdapat 3 anak dengan lingkar kepala $<5^{\text {th }}$ persentil dan $>95^{\text {th }}$ persentil dan ketiganya merupakan anak dengan status $\mathrm{fT}_{4}$ rendah. Sesuai dengan interpretasi data persentil WHO, maka ketiga anak ini akan mengalami gangguan perkembangan mental. Hasil analisis data menunjukkan nilai $\mathrm{p}=0,309 \quad(>0,05)$ maka tidak terdapat korelasi signifikan di antara kedua variabel.

Sebanyak $60 \%$ dari $23,2 \%$ anak dengan persentil lingkar lengan atas di luar batas normal adalah anak dengan $\mathrm{fT}_{4}$ rendah. Ditemukan sejumlah kecil anak memiliki kecenderungan untuk memiliki berat badan lebih di kemudian hari yaitu sebanyak 18,6\% dari populasi sampel. Tetapi secara rata-rata pertumbuhan fisik anak di daerah endemik GAKY Kecamatan Srumbung, Magelang adalah baik dengan perbaikan untuk beberapa anak dengan kadar $\mathrm{fT}_{4}$ yang rendah maupun pengawasan untuk beberapa anak dengan kadar $\mathrm{fT}_{4}$ yang normal tetapi memiliki indikasi gangguan pertumbuhan.

Berdasarkan hasil uji statistik Spearman, didapatkan korelasi negatif antara $\mathrm{fT}_{4}$ dengan Lingkar lengan atas. Lingkar lengan atas menunjukkan simpanan jaringan lemak subkutan dan visceral pada anak dan sudah digunakan oleh NHANES untuk menentukan ukuran manset sphygmomanometer ${ }^{25}$. Sebuah penelitian menunjukkan bahwa pemberian terapi pengganti tiroksin L-
Thyroxine pada individu dengan hipotiroid subklinis menunjukkan turunnya apolipoprotein B-48 yaitu salah satu lipoprotein yang diikat oleh $\mathrm{Tg}$ pada pasien dengan hipotiroidisme dan merupakan seromarker resiko atherosclerosis. Turunnya TSH dan peningkatan $\mathrm{fT}_{4}$ setelah diberikan terapi hormon pengganti diikuti dengan penurunan ApoB-48 $(\mathrm{r}=0.39, \mathrm{p}<0.05)$. Hal ini menunjukkan bahwa semakin tinggi kadar $\mathrm{fT}_{4}$ akan menurunkan kadar lemak berlebih dalam tubuh ${ }^{26}$.

Sementara itu, kadar $\mathrm{fT}_{4}$ dengan berat badan menunjukkan terdapat korelasi sedang dengan arah korelasi positif di mana semakin optimum kadar $\mathrm{fT}_{4}$ seseorang maka akan semakin baik status gizinya. Hal ini sesuai dengan teori bahwa fungsi efek hormon tiroid meningkatkan metabolisme tubuh ${ }^{27}$.

Untuk anak-anak yang memiliki kadar $\mathrm{fT}_{4}$ rendah dapat dilakukan terapi tiroksin pengganti. Terapi pengganti tiroksin pada usia dini akan memperbaiki status gizi yang lebih baik. pemberian terapi pengganti hormon tiroid berupa LThyroxine berkorelasi signifikan dengan kecepatan pertumbuhan fisik dengan dosis dan waktu pemberian terapi hormon pengganti $(r=-0.34 ; \mathrm{p}<0.05)$. Maka dari itu pengawasan fungsi tiroid dan pemberian terapi pengganti hormon tiroid sebaiknya dilakukan sejak awal dan sedini mungkin sehingga dapat memperbaiki pertumbuhan dan perkembangan anak 
dengan gangguan fungsi tiroid ke depannya ${ }^{28}$.

Hubungan $\mathrm{fT}_{4}$ dengan panjang badan terdapat korelasi yang bermakna, korelasi lemah, dan arah korelasi positif. Anak-anak dengan hipotiroidisme subklinis memiliki kadar kerapatan tulang yang normal dan struktur maupun pertumbuhan tulang yang normal. Walaupun pada teorinya, hormon tiroid memerankan peran penting terhadap pertumbuhan tulang paska kelahiran seseorang dengan cara mempengaruhi pembentukan dan remodeling tulang selama pertumbuhan ${ }^{29}$. Tetapi pada akhirnya faktor yang paling berpengaruh pada kelompok pasien dan kelompok kontrol adalah faktor genetik dari orangtua masing-masing ${ }^{30}$.

Tidak adanya korelasi signifikan antara kadar $\mathrm{fT}_{4}$ lingkar kepala mungkin disebabkan karena sistem saraf pusat merupakan sebuah bangunan kompleks yang perkembangannya dipengaruhi oleh banyak hal. Selain itu pengukuran lingkar kepala merupakan evaluasi paling sederhana, mendasar, dan murah untuk dilakukan sebagai untuk memperkirakan perkembangan sistem saraf pusat pada neonatus yang berada pada resiko tinggi gangguan perkembangan otak ${ }^{24}$. Hasil pengukuran menunjukkan terdapat 3 anak dengan lingkar kepala $<5$ th persentil dan $>95$ th persentil dan ketiganya merupakan anak dengan status fT4 rendah. Sesuai dengan interpretasi data persentil WHO, maka ketiga anak ini akan mengalami gangguan perkembangan mental. Hasil analisis data menunjukkan nilai $\mathrm{p}=0,309$ $(>0,05)$ maka tidak terdapat korelasi signifikan di antara kedua variabel. Tidak signifikannya korelasi $\mathrm{fT}_{4}$ dengan berat badan-panjang badan dan BMI kemungkinan besar disebabkan karena kurang luasnya range sampel untuk kadar $\mathrm{fT}_{4}$

Pembahasan di atas menunjukan bahwa 3 dari 6 indikator pertumbuhan fisik anak memiliki hubungan yang bermakna dengan status $\mathrm{fT}_{4}$ darah. Hal ini membuktikan sebagian teori yang menyebutkan $\mathrm{fT}_{4}$ merupakan salah satu hormon yang mempengaruhi pertumbuhan. Korelasi positif antara status $\mathrm{fT}_{4}$ dengan berat badan dan panjang badan menunjukkan semakin tinggi hormon $\mathrm{fT}_{4}$ darah, maka indeks pertumbuhan fisik berupa dua hal tersebut akan semakin tinggi juga. Tetapi tinggi yang dimaksud di sini adalah mencapai kadar optimum dan tidak berlebih. Semakin dini terdeteksi kelainan pertumbuhan, maka akan semakin baik prognosis ke depannya.

Selain peran hormon, faktor faktor lain yang mempengaruhi pertumbuhan fisik atau antropometri anak yaitu faktor internal (genetik, obstetrik, gender), faktor eksternal yang meliputi faktor prenatal (gizi, mekanis, toksin/ zat kimia, endokrin, radiasi, infeksi, psikologi ibu), faktor persalinan (trauma kepala, 
asfiksia), dan pascasalin (gizi, penyakit kronis/ kelainan kongenital, lingkungan fisis dan kimia, psikologis, endokrin, sosio-ekonomi, lingkungan pengasuhan, stimulasi dan obat-obatan). Di antara semua faktor lainnya ini, yang paling memungkinkan dan biasa menjadi penyebab gangguan pertumbuhan ialah asupan gizi yang kurang sesuai dengan kebutuhan anak dan usia anak yang masih berada dalam masa pertumbuhan. Sebuah review artikel menyebutkan bahwa pertumbuhan tulang membutuhkan keseimbangan asupan kalsium dan natrium yang berperan dalam optimalisasi massa tulang pada anak, dibutuhkan diet yang tinggi akan produk susu, protein dan buah-buahan disertai dengan aktivitas anak sebelum dan sesudah pubertas ${ }^{31}$.

Berdasarkan data yang diambil dari 43 responden didapatkan hasil yaitu jumlah penderita hipotiroid pada anak dibawah 2 tahun. Di daerah GAKY, Srumbung, Magelang adalah sebanyak 19 orang $(44,2 \%)$ dan anak dengan kadar tiroid normal adalah sebanyak 31 orang (73\%) hal ini berarti bahwa rata-rata kadar tiroksin bebas darah (fT 4$)$ darah pada anak usia bawah 2 tahun ada dalam batas normal.

Hasil penelitian ini memperlihatkan bahwa terdapat 4 indikator lain yang tidak menunjukkan korelasi signifikan, yaitu perkembangan motorik kasar, motorik halus, bahasa, dan personal sosial. Hal ini menunjukkan bahwa rata-rata anak usia bawah dua tahun di daerah tersebut telah mengalami perkembangan motorik kasar normal meskipun status tiroksin bebas darah yang rendah.

$$
\text { Perkembangan bahasa atau }
$$
kemampuan berbicara pada anak usia 0 2 tahun juga dipengaruhi oleh beberapa faktor diantaranya yaitu persiapan fisik dan kesiapan mental untuk bicara, bimbingan model yang baik untuk ditiru (antara lain orang di lingkungannya, radio, televisi, film), kesempatan untuk berpraktek atau berlatih bicara dan motivasi (bila tanpa bicara sudah memperoleh yang diinginkan maka motivasi untuk belajar jadi lemah) ${ }^{32}$. Perkembangan sosial anak sangat dipengaruhi oleh proses perlakuan atau bimbingan orangtua terhadap anak dalam mengenalkan berbagai aspek kehidupan sosial, atau norma-norma kehidupan bermasyarakat serta mendorong dan memberi contoh kepada anaknya bagaimana menerapkan norma-norma tersebut dalam kehidupan sehari-hari. Proses bimbingan orangtua ini lazim disebut sosialisasi ${ }^{33}$. Berbagai factor lain yang berpengaruh terhadap perkembangan anak adalah faktor internal yang meliputi ras/etnik, keluarga, genetic, kemudian yang kedua dari faktor eksternal seperti gizi, infeksi, dan persalinan. Faktor lain yang tidak dapat dilepaskan dari pertumbuhan dan perkembangan anak adalah faktor sosial ekonomi ${ }^{34}$. Kemiskinan selalu berkaitan dengan 
kekurangan makanan, kesehatan lingkungan yang jelek, serta kurangnya pengetahuan $^{35}$.

Sejalan dengan penelitian Sofia, dkk. (2010) tentang perkembangan sel otak remaja yang dinilai dengan nilai IQ di daerah endemik GAKY didaerah lemah Dadi, Bantul dan Karangwuluh, Kulonprogo yang menunjukan tidak terdapat korelasi bermakna antara asupan yodium dengan nilai IQ remaja di daerah endemik GAKY. Terdapat berbagai factor yang mempengaruhi perkembangan sel otak, termasuk status gizi, genetic, pendidikan dan psikologi ${ }^{36}$.

Pertumbuhan dan perkembangan anak usia bawah 2 tahun di daerah endemik gondok di kabupaten Jombang, Jawa timur, menunjukan bahwa pola pertumbuhan anak dari ibu penderita gondok dan bukan penderita gondok tidak berbeda, namun perkembangan anak dari ibu bukan penderita gondok secara umum lebih baik dari pada anak ibu penderita gondok ${ }^{37}$. Pengukuran IQ remaja di daerah endemic GAKY Karangwuluh Kulon Progo Yogyakarta dan Lemahdadi Bantul didapatkan 90\% remaja memiliki rata-rata IQ normal rendah 8

Perkembangan bahasa atau kemampuan berbicara pada anak usia 0 2 tahun juga dipengaruhi oleh beberapa faktor lainnya seperti Gizi ibu pada waktu hamil, Status gizi anak, Stimulasi yang di berikan untuk anak secara terarah dan teratur (berjalan, berlari, melompat, dan naik turun tangga) dan pengetahuan ibu juga mempunyai peranan sangat penting pada anak ${ }^{32}$

Walaupun hasil penelitian crosssectional ini menunjukkan tidak terdapatnya korelasi signifikan antara kadar free Thyroxine darah dengan pertumbuhan maupun perkembangan anak bawah 2 tahun, tetapi harus diingat hormonhormon tiroid merupakan hormon yang bekerja dan berpengaruh dalam jangka yang lama, dan berpengaruh terhadap metabolisme tubuh ${ }^{27}$. Maka dari itu, pendeteksian dini akan kadar hormon tiroid baik $\mathrm{fT}_{4}$ jika memungkinkan sebaiknya dilaksanakan pada anak-anak dengan usia golden period ini, sehingga bilamana terdeteksi suatu kelainan maka tatalaksana dapat segera diberikan untuk mencegah terjadinya dampak yang lebih jauh lagi di kemudian hari.

\section{KESIMPULAN}

Kejadian hipotiroid di Ngargosoko, Kecamatan Srumbung, Kabupaten Magelang saat ini telah kecukupan intake yodium dengan median kadar yodium urin sebesar 296 ug/dL, rata-rata kadar TSH dan fT4 darah berturutan adalah 1.7187 $\mu \mathrm{IU} / \mathrm{ml}$ dan $0.8545 \mathrm{ng} / \mathrm{dL}$. Akan tetapi masih diperoleh responden hipotiroid sebesar $50,84 \%$.

Kadar tiroksin bebas darah menentukan berat badan, panjang badan dan lingkar lengan, tapi tidak menentukan 
besar lingkar kepala, indeks masa tubuh, perkembangan motorik kasar, motorik halus, bahasa dan personal social.

Perkembangan anak perlu diukur dengan alat ukur yang lebih baik misalnya dengan Bayley Scale of Infant Development (BSID).

\section{SUMBER DANA}

Penelitian ini terlaksana atas dana dari LP3M UMY dan FKIK UMY

\section{DAFTAR PUSTAKA}

1. Djokomoeljanto. (1998). Konsekuensi GAKY Terhadap Kualitas Sumber Daya Manusia. Lokakarya Hasil Survei Nasional Pemetaan Gaky. Jakarta.

2. AK, T. (2006). Athyreosis, dysgenesis, and dishormogenesys in congenital hypothiroidism. Pediatr Endocrinol Rev 3 , 498.

3. Gallahue, D. J. (1998). Understanding Motor Development Infant, Children, Adolecents, Adults. 4th ed. New York, San Fransisco: Mc Graw-Hill Book Co.

4. Hertherington, E. \&. (1999). Child Psychology : Contemporary View Point. 5th ed. USA: Mc Graw-Hill, Inc.

5. Ergur, (2011) Neurocognitive Functions in Children and Adolescents with Subclinical Hypothyroidism

6. Jameson, J. L. (2012). Disorder of the Thyroid Gland. Dalam D. L. Longo, Harrison's Principles of Internal Medicine ed.18 (hal. 2915). United States of America: McGraw Hill.

7. Wirawan A, Sunartini, Suryawan Bikin, Soetjiningsih. 2013. Tumbuh kembang anak hipotiroid kongenital yang diterapi dini dengan levotiroksin dan dosis awal tinggi. Sari Pediatri 2013;15:69-74.
8. Noor., e. a. (2010). Hubungan Kadar T4 Bebas dengan Tumbuh Kembang Remaja Usia 12-16 tabun di Daerah Gondok Endemik dan non-endemik. Yogyakarta.

9. Coplan, J. (2011). Making Sense of Autistic Spectrum Disorder. Dipetik April 16, 2012, dari www.drcoplan.com: www.drcoplan.com/early-languagemilestone-scale- 2

10. P.Weetman, A. (2012). Disorder of the Thyroid Gland. Dalam D. Longo, Harrison's Principles of Internal Medicine ed.18 (hal. 2914). United States of America: McGraw Hill.

11. Soeharyo H, M. A. (2002). Aspek Sosio-Kultural Pada Program Penanggulangan GAKY. Jurnal GAKY Indonesia (Indonesian Journal of IDD) , 43.

12. Menkes. (2002). Klasifikasi Status Gizi Anak. Kepmenkes Nomor:920/Menkes/SK/VII/2002, Departemen Kesehatan RI.

13. Hurlock. (1993). Perkembangan Anak Edisi VI Jilid I. Jakarta: Erlangga.

14. Celine M Murrin, G. E. (2012). Bod Mass Index and Height over Three Generations : evidence from he Lifeways cross-generational cohor study. BMC Public Health , 12:81.

15. Andrew Friede., e. a. (1987). Young Maternal Age and Infant Mortality: the Role of Low Birth Weight. Public Health Reports Vol. 102, No. 2 MarchApril, 192:199.

16. Feigelman, S. (2011). Growth, Development, and Behavior. Dalam M. Robert M. Kliegman, Nelson Textbook of Pediatrics (hal. 26;33). United States of America: Elsevier Saunders.

17. Kostoglou-Athanassinou, Ntalles K. (2010). Hypothyroidism-new Aspects of an Old Disease. Hippokratia, 8287.

18. Benvenga S, C. A. (2000). Hypopituitarism secondary to head 
trauma. Clin Endocr Metab , 85:13536.

19. Ambika Gopalakrishnan Unnikrishnan, S. K. (2013 Jul-Aug;). Prevalence of hypothyroidism in adults: An epidemiological study in eight cities of India. Indian J Endocrinol Metab. , 17(4): 647-652.

20. Gudmundsdottir A, S. J. (2002). Central hypothyroidism. Endocrinologist, 12:218-23.

21. Vishal Gupta, M. L. (2011 July;). Central Hypothyroidism. Indian J Endocrion Metab, S99-S106.

22. Eltom A, e. a. (2001). Thyroid Function in the newborn in relation to maternal thyroid status during labour in a mild iodine deficiency endemic area in Sudan. Clin Endocrinal (Oxf), Oct;55 , 485-90.

23. Yadav S, e. a. (2010). Persistence in severe iodine deficiency disorders despite universal salt iodization in an iodine deficient area in northern india. Public Health Nutr, Mar;13, 424-9

24. Maharani, D. D. (2010). Hubungan antara Kadar Tiroksin Bebas dengan Tingkat Intelligence Quotient pada Remaja Usia 12 - 16 tahun di Daerah Gondok Endemik dan Non Endemik. Yogyakarta: Fakultas Kedokteran dan Ilmu Kesehatan Universitas Muhammadiyah Yogyakarta.

25. CDC. (2007). Anthropometry Procedures Manual. United States of America: National Health and Nutrition Examination Survey (NHANES).

26. Mitsuru Ito, A. K. (2013). Effect of L-thyroxine replacement on apolipoprotein B-48 in overt and subclinical hypothyroid patients. Endocrine Jorunal , 60 (1), 65-71.

27. Guyton, M. (2008). Buku AJar Fisiologi Kedokteran Edisi 9. Jakarta: Penerbit Buku Kedokteran EGC.

28. Karolina Kowalczyk, K. P. (2013). Lthyroxine Therapy and Growth
Processes. Endocrine Journal, 60 (1), 65-71.

29. Gogakos Al, D. B. (2010). Thyroid and Bone. Arch Biochem Biophys Ed.503 , 29-136.

30. Raffaella Di Mase, M. C. (2012). Bone Health in Children with Longterm idiopathic Subclinical Hypothyroidism. Journal of Pediatrics, 28:56.

31. Connie M Weaver, P. (2008). The Role of Nutrition on Optimizing Peak Bone Mass. Asia P Ac J Clin Nutr:17 (S1) , 135-137.

32. Soetjiniangsih. (1995). Tumbuh Kembang Anak. Jakarta: Penerbit Buku Kedokteran EGC.

33. Harditono. (2001). Psikologi Perkembangan. Yogyakarta: Gajah Mada University press.

34. Djokomoeljanto. (2006). Gangguan Akibat Kekurangan Iodium. Dalam B. S. Aru W. Sudoyo, Buku Ajar Ilmu Penyakit Dalam. Jakarta: Pusat Penerbitan Departemen Ilmu Penyakit Dalam Fakultas Kedokteran Universitas Indonesia.

35. Djokomoeljanto. (2010). Kelenjar Tiroid, Hipotiroidisme, dan Hipertiroidisme. Dalam A. W. Sudoyo, Buku Ajar Ilmu Penyakit Dalam Edisi V (hal. 1997). Jakarta: Interna Publishing.

36. Djokomoeljanto. (2010). Kelenjar Tiroid, Hipotiroidisme, dan Hipertiroidisme. Dalam A. W. Sudoyo, Buku Ajar Ilmu Penyakit Dalam Edisi V (hal. 1997). Jakarta: Interna Publishing.

37. Gamayanti. (1997). Tumbuh Kembang Anak. Materi Pelatihan Deteksi Dini Penyimpangan dan Pemantauan Tumbuh Kembang Anak. 